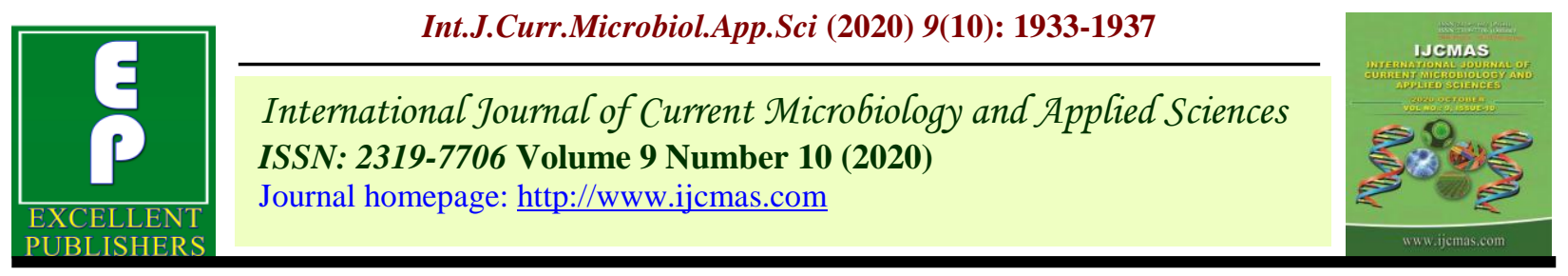

Original Research Article

https://doi.org/10.20546/ijcmas.2020.910.236

\title{
Effect of Levels of Phosphorus and Zinc on Growth and Yield of Blackgram (Vigna mungo L.)
}

\author{
Konda Saikishore*, Vikram Singh and Dhananjay Tiwari
}

Department of Agronomy, Naini Agricultural Institute SHUATS, Prayagraj (U.P.) India

*Corresponding author

\author{
A B S T R A C T
}

\begin{tabular}{l} 
Ke y w or d s \\
Black gram, \\
$\begin{array}{l}\text { Phosphorus, Zinc, } \\
\text { Growth, Yield }\end{array}$ \\
\hline Article Info \\
$\begin{array}{l}\text { Accepted: } \\
15 \text { September } 2020 \\
\text { Available Online: } \\
10 \text { October } 2020\end{array}$ \\
\hline
\end{tabular}

A field experiment was conducted at Crop Research Farm (CRF), SHUATS, Prayagraj, in the crop black gram in zaid season of 2019, with 9 treatments which were replicated thrice and laid out in a RBD. The experiment consisted of three levels of Phosphorus, viz., which were soil applied at the time of sowing and three-time application of foliar spray of zinc. Among the treatments, $50 \mathrm{~kg} \mathrm{ha}^{-1}$ of Phosphorus along with foliar spray $\mathrm{Zn}$ at $15,30 \& 45$ DAS had recorded overall higher data in plant height $(37.63 \mathrm{~cm})$, number of branches (5.80/plant), number of nodules (46.73/plant), dry weight (5.92 g/plant),CGR(5.28 $\mathrm{g} / \mathrm{m}^{2} /$ day $)$, number of pods/plant $(39.2$ pods/plant), number of seeds/plant (4.68 seeds/pod), test weight (35.66 g), seed yield (0.66 t/ha), biological yield $(1.40 \mathrm{t} / \mathrm{ha})$, harvest index $(32.66 \%)$ and protein content $(22.98 \%)$. Also, the highest net return (Rs 30210.84/ha), gross return (Rs 45011.2/ha) and B:C ratio (2.11)were recorded higher in 50 $\mathrm{kg} \mathrm{ha}^{-1}$ of Phosphorus $+15,30$ \& 45 DAS Zinc Foliar Spray.

\section{Introduction}

Black gram (Vigna mungo L. Hepper) is one of the important pulse crops grown throughout India. It is a protein rich $(25$ per cent) staple food containing almost three times that of cereals. Black gram accounts for 10 per cent of total pulse production in India (Phogat, 2016). Among pluses, blackgram (Urdbean) contributes $16.28 \%$ of the total area and $11.48 \%$ of the total production with an average productivity of $451.6 \mathrm{~kg} \mathrm{ha}^{-1}$ (Jamra, 2016). India has become selfsufficient with respect to production of cereals but still lags behind with respect to the production of pulses, even though it is the largest producer of pluses in the world.
Black gram, being a pulse crop requires high amount of phosphorus (P). The adequate supply of phosphorus to legume is more important than that of nitrogen because it has beneficial effect on nodulation and nitrogen fixation, root development, growth and yield (Kumar, 2008). The most deficient micronutrient in Indian soils is zinc, in fact, zinc is regarded as the third most important limiting nutrient in crop production after nitrogen and phosphorus (Takkar and Randhawa, 1980). Zinc is involved in the channelization of photosynthesis during reproductive stage by way of its involvement in electron transfer (Baker et al., 1982).Among the interactions involving macro and micronutrients the interaction 
between phosphorus and zinc is of greatest potential significance. This interaction is often antagonistic especially when a soil is deficient in both the nutrients and only one of them is applied through fertilizers.

\section{Materials and Methods}

The experiment was carried out during kharif season of 2018 at the Crop Research Farm (CRF) Department of Agronomy, Naini Agricultural Institute, SHUATS, Prayagraj, Uttar Pradesh. The soil of the experimental area was sandy loam. Soil sample was taken before and after sowing with soil auger and analyzed. The effectiveness of levels of phosphorus and zinc was evaluated through a field experiment in black gram crop. The experiment was laid out in a RBD with three replications with a plot size of $3 \times 3 \mathrm{~m}$. Pant $\mathrm{U}-19$ a black gram variety was grown with a spacing of $30 \times 10 \mathrm{~cm}$.

Three levels of phosphorus and zinc were applied in the respective plots according to the treatments just before sowing of the seed in a line, and the quantity was based on $\mathrm{N}$ : P: $\mathrm{K}$ requirement of crop. Observations such as average plant height, number of nodules, dry weight, number of pods, were recorded by taking average of 5 plants and treatment-wise. Seed and straw yields were recorded per plot and converted into t/ha. Data generated from the field experiments were subjected to the statistical analyses of variance appropriate to the experimental design.

\section{Results and Discussion}

As seen in table 1 at 60 DAS significantly higher plant height was observed in $\mathrm{T}_{9} 50 \mathrm{~kg}$ $\mathrm{ha}^{-1}$ of Phosphorus $+15,30 \& 45$ DAS Zn Foliar Spray recording $35.86 \mathrm{~cm}$. Also, growth parameters like no. of nodules per plant and dry weight at 45 and 60 DAS respectively, were significantly higher in $T_{9}$
$50 \mathrm{~kg} \mathrm{ha}^{-1}$ of Phosphorus $+15,30 \& 45$ DAS Zn Foliar Spray recording 39.26 nodules/plant and $5.92 \mathrm{~g} /$ plant respectively.

Tuncturk and Tuncturk (2006) favorable effect of phosphorus on growth parameters due to effective utilization of nutrients through the extensive root system developed by crop plants under phosphorus application. Enhanced plant height with foliar spray of zinc was reported by El-Habbasha et al., (2013), Singh and Bhatt (2013) and Malik et al., (2015). Also, Singh and Singh (2004) reported that application of $\mathrm{P}$ increased the total dry matter yield of black gram (Vigna mungo). Zinc helps in chlorophyll formation which might have resulted in better interception and utilization of radiant energy leading to higher photosynthetic rate and finally increased dry matter production. Increased dry matter production as function of increased photosynthetic efficiency with the application of zinc might have seen from increase in CGR.

It is observed that significantly higher seed yield were higher in $\mathrm{T}_{9} 50 \mathrm{~kg} \mathrm{ha}^{-1}$ of Phosphorus + 15, $30 \& 45$ DAS Zinc Foliar Spray recording $0.66 \mathrm{t} / \mathrm{ha}$ respectively. Net return was significantly higher in treatment $\mathrm{T}_{9}$ $50 \mathrm{~kg} \mathrm{ha}^{-1}$ of Phosphorus $+15,30 \& 45$ DAS Zinc foliar spray having Rs.30210.84. Benefit cost ratio was significantly superior in treatment $\mathrm{T}_{9} 50 \mathrm{~kg} \mathrm{ha}^{-1}$ of Phosphorus +15 , $30 \& 45$ DAS Zinc foliar spray having 2.11.

Phosphorus plays a primary role in photosynthesis by way of energy transfer and thereby increases photosynthetic efficiency resulting in increased availability of photosynthates. Zinc plays a pivotal role in cellular growth, differentiation and metabolism which results in vigorous growth of plants which probably led to higher number of pods. Similar results were found by Choudhary (2006) and Sammauria (2007). 
Table.1 Effect of phosphorus and zinc on growth and yield of black gram

\begin{tabular}{|c|c|c|c|c|c|c|c|}
\hline \multicolumn{2}{|r|}{ Treatment combinations } & $\begin{array}{c}\text { Plant height } \\
\text { (cm) }\end{array}$ & $\begin{array}{c}\text { Nodules } \\
\text { /plant }\end{array}$ & $\begin{array}{l}\text { Dry weight } \\
\text { (g/plant) } \\
4.31\end{array}$ & $\begin{array}{c}\begin{array}{l}\text { Seed yield } \\
\text { (t/ha) }\end{array} \\
0.56\end{array}$ & $\begin{array}{l}\begin{array}{l}\text { Net return } \\
\text { (Rs/ha) }\end{array} \\
25897.72\end{array}$ & $\begin{array}{l}\mathrm{B:C} \\
\text { ratio } \\
1.96\end{array}$ \\
\hline $\mathbf{T}_{2}$ & $30 \mathrm{~kg} \mathrm{ha}^{-1}$ of $\mathrm{P}+\mathrm{Zn}$ Spray $15 \& 30 \mathrm{DAS}$ & 33.66 & 4.14 & 4.33 & 0.56 & 25853.42 & 1.92 \\
\hline $\mathbf{T}_{4}$ & $40 \mathrm{~kg} \mathrm{ha}^{-1}$ of $\mathrm{P}+\mathrm{Zn}$ Spray 15 DAS & 30.16 & 4.67 & 5.06 & 0.59 & 26721.74 & 1.91 \\
\hline $\mathbf{T}_{5}$ & $40 \mathrm{~kg} \mathrm{ha}^{-1}$ of P + Zn Spray $15 \& 30$ DAS & 33.50 & 3.74 & 4.81 & 0.60 & 27575.27 & 1.95 \\
\hline $\mathbf{T}_{6}$ & $40 \mathrm{~kg} \mathrm{ha}^{-1}$ of $\mathrm{P}+\mathrm{Zn}$ Spray $15,30 \& 45 \mathrm{DAS}$ & 34.50 & 3.68 & 5.22 & 0.61 & 27635.94 & 1.94 \\
\hline $\mathbf{T}_{8}$ & $50 \mathrm{~kg} \mathrm{ha}^{-1}$ of $\mathrm{P}+\mathrm{Zn}$ Spray $15 \& 30$ DAS & 36.40 & 3.95 & 5.51 & 0.64 & 29167.9 & 1.98 \\
\hline $\mathbf{T}_{9}$ & $50 \mathrm{~kg} \mathrm{ha}^{-1}$ of $\mathrm{P}+\mathrm{Zn}$ Spray $15,30 \& 45$ DAS & 37.63 & 3.71 & 5.92 & 0.66 & 30210.84 & 2.11 \\
\hline & F-Test & $\mathrm{S}$ & NS & S & $\mathrm{S}$ & $\mathrm{S}$ & S \\
\hline & SEm \pm & 1.25 & 0.41 & 0.09 & 0.01 & 374.25 & 0.03 \\
\hline & $\mathrm{CD}(\mathrm{P}=0.05)$ & 4.73 & - & 0.26 & 0.02 & 1121.83 & 0.09 \\
\hline
\end{tabular}


Such increase in seed yield was reported by Panwar et al., (1978) and Ingale (1994). Gupta et al., (2006) also observed the significant response on black gram seed yields with higher doses of $P$. The increase in the yield attributes might also be due to role of zinc in biosynthesis of indole acetic acid (IAA) and especially due to its role in initiation of primordia for reproductive parts and partitioning of photosynthates towards them, which resulted in better flowering and fruiting.

On the basis of the research findings we can conclude that application of $50 \mathrm{~kg} \mathrm{ha}^{-1}$ of Phosphorus + 15, $30 \& 45$ DAS Zinc Foliar Spray overall recorded higher growth, yield economic parameters.

\section{References}

Baker, N.R., Feryhough, P. and Meek, T.T. 1982. Light dependent inhibition of photosynthetic electron transport of zinc. Plant Physiology, 56: 217-222.

Choudhary, M. 2006. Response of cluster bean to sulphur and zinc fertilization. M.Sc. (Ag.) Thesis, Rajasthan Agricultural University, Bikaner.

El-Habbasha, S.F., Mohamed, M.H., ElLateef, E.M.A., Mekki, B.B and Ibrahim, M.E. 2013. Effect of combined zinc and nitrogen on yield, chemical constituents and nitrogen use efficiency of some chickpea cultivars under sandy soil conditions. World Journal of Agricultural Sciences 9(4): 354-360.

Gupta, K. 2006.Role of Phosphorus and Zinc in Enhancing Growth, Yield and Quality of Fennel Crop (Foeniculum vulgare Mill.) in Irrigated Conditions of North West Rajasthan. Phd thesis submitted to Swami Keshwanand Rajasthan Agricultural University, Bikaner.
Ingale, D.S. 1994. Effect of sources and levels of phosphorus on growth and yield of green gram (Vigna radiata L.). A dissertation submitted to M.K.V. Parbhani for M.Sc. (Agri.) degree. Rajasthan Agricultural University, Bikaner.

Jamra, K.U., 2016. Effect of Different Levels and Sources of Phosphorus on Yield and Chemical Composition of Blackgram (Phaseolus mungo L.) in Alluvial Soil of Northern Madhya Pradesh. M.Sc Thesis submitted to Rajmata Vijayaraje Scindia Krishi Vishwa Vidyalaya, Gwalior.

Kumar, G. 2008. Influence of P, S and phosphate solubilizing bacteria on productivity of blackgram -toria cropping sequence. PhD thesis submitted to Birsa Agricultural University RanchI, Jharkhand.

Malik, K., Kumar, S and Arya, K. P. S. 2015. Effect of zinc, molybdenum and urea on growth and yield of mung bean (Vigna radiata L. Wilczek). Advance Research Journal of Crop Improvement. 6 (1): 59-65.

Panwar, K.S.; Pandey, K. and Singh, M. 1978. Response of some promising varieties of moong to levels of phosphorus. Indian J. Agron. 23; 366367.

Phogat, M., 2016.Effects of phosphorus and sulphur interaction on blackgram in rice-blackgram cropping system of coastal saline soils. Legume Research31 (2): 79-86.

Sammauria, R. 2007. Response of fenugreek to phosphorus and zinc application and their residual effect on succeeding pearlmillent under irrigated condition of western Rajasthan Ph.D. (Ag.) Thesis, Rajasthan Agricultural University, Bikaner.

Singh, A. K and Bhatt, B. P. 2013. Effect of foliar application of zinc on growth and 
seed yield of late-sown lentil. Indian Journal of Agricultural Sciences, 83(6): 622-626.

Singh, Y.P. and Singh, R. 2004. Interaction effect of sulphur and phosphorus on growth and nutrients content of black gram (Phaseolus mungo L.). Journal of the Indian Society of Soil Science 52(3): 266-269.

Takkar, P.N. and Randhawa, N.S. 1980. Zinc deficiency in Indian soils and plants.
Seminar on zinc wastes and their utilization, 15- 16 Oct., 1980. Organized by India Lead Zinc Information Centre and the fertilizer Association of India.

Tuncturk, R. and Tuncturk, M. 2006. Effect of different phosphorus levels on the yield and quality components of cumin (Cuminum cyminum L.). Res. J. Agril. Biol. Sci. 2(6): 336-340.

\section{How to cite this article:}

Konda Saikishore, Vikram Singh and Dhananjay Tiwari. 2020. Effect of Levels of Phosphorus and Zinc on Growth and Yield of Blackgram (Vigna mungo L.). Int.J.Curr.Microbiol.App.Sci. 9(10): 1933-1937. doi: https://doi.org/10.20546/ijcmas.2020.910.236 